\title{
Endoxana (cyclophosphamide) in the treatment of intracerebral malignancy
}

\author{
F. CLIFFORD ROSE, S. N. BHAGWATI, AND WYLIE MCKISSOCK \\ From Atkinson Morley's (St. George's) Hospital, London
}

The limitations of treatment in malignant growths in the brain are too well known to need comment. In patients with cerebral metastases or astrocytomas of grade III and IV malignancy the survival period is usually to be measured in months. Conventional methods of surgery and radiotherapy have proved unsuccessful. The use of a cytotoxic drug with a selective action on the tumour cells, sparing the normal cells of the body, seems to be an ideal method of treating infiltrating and malignant tumours of the brain. Endoxana (cyclophosphamide), a nitrogen mustard derivative, was chosen because it has a relatively wider margin of safety and a lesser tendency to depression of haemopoietic tissues than many other alkylating agents.

\section{CASE MATERIAL}

Fourteen patients, 12 with cerebral gliomas and two with cerebral metastases, admitted to Atkinson Morley's (St. George's) Hospital, were given varying courses of this drug.

All cases of malignant glioma were proven histologically, with one exception in which, though there was little doubt macroscopically about the existence of an infiltrating cystic astrocytoma, the histological examination had failed to show definite tumour tissue. Of the two cases of cerebral metastases, one was proved by burr-hole biopsy and the other had widespread metastases elsewhere.

\section{MODE OF USE}

After a complete blood count, a test dose of $100 \mathrm{mg}$. of Endoxana was given intravenously. If this did not produce any undue nausea, vomiting, or depression of the haemopoietic system, the patient was given $400 \mathrm{mg}$. of Endoxana intravenously daily. Blood counts were performed each day, a close watch being kept on the total number of leucocytes. Intravenous therapy was continued until the total white count fell to about 2,000/c.mm., and the patient was then given $50 \mathrm{mg}$. of Endoxana orally twice a day, blood counts being carried out less frequently, but usually twice or three times a week.

The dosage of oral Endoxana was varied so as to maintain a total leucocyte count of about $2,000 / \mathrm{c} . \mathrm{mm}$. Once the appropriate maintenance dose was established, the patients were discharged from hospital and treated as outpatients, a weekly check on the blood picture being mair
tained.

On average, about 4 or $5 \mathrm{~g}$. Endoxana had to be given intravenously before the total white blood cell courf reached a level of about 2,000/c.mm. Endoxana, $100 \mathrm{mg}$. orally each day, was sufficient in most cases as a mainterp ance dose, though in three cases this had to be increased to $200 \mathrm{mg}$.

\section{RESULTS}

The results are set out in Table I. The first patienti treated (case 1) was stuporose and died after receiving the drugfor only five days. As it was felt that Endoxañ was unlikely to lead to dramatic relief in a few dô it was subsequently given only to patients in good general condition who were not in danger of dyring immediately. The remaining 13 cases fulfilled criterion.

In eight of the 14 cases (cases 1, 2, 3, 4, 5, 7, 9, 14) no surgical internal decompression was mates before the commencement of Endoxana therapy, the tumour having been verified by burr-hole biopsyo Case 4 developed pneumonia due to a resistank staphylococcus, the drug was discontinued, and the patient died within two weeks, there having been no" sign of regression of the tumour. Case 7, after being treated with Endoxana for two weeks, developed jaundice which, on investigation, was of the ob 3 structive type. The jaundice cleared within two weekso on discontinuing the drug, and a further course waș not given; the patient died six months later from a recurrence of the glioma. The other five cases, after some initial improvement, soon showed obvious signs of continued growth of the tumour and died in?. periods of one to six months from the time Endoxana therapy began.

\section{CONCOMITANT SURGICAL THERAPY}

In one patient (case 11) a moderate amount of tumour was removed through a trephine disc, thus achieving a slight internal decompression. This $N$ patient remained in good condition at first, but even- N 
TABLE I

\begin{tabular}{|c|c|c|c|c|c|c|c|c|c|c|c|}
\hline \multirow[b]{2}{*}{$\begin{array}{l}\text { Case } \\
\text { No. }\end{array}$} & \multirow[b]{2}{*}{ Initial } & \multirow[b]{2}{*}{$\operatorname{Sex}$} & \multirow[b]{2}{*}{$\begin{array}{l}\text { Age } \\
\text { (yr.) }\end{array}$} & \multirow[b]{2}{*}{ Type of Tumour } & \multicolumn{3}{|c|}{ ANALYSIS OF 14 CASES } & \multirow{2}{*}{$\begin{array}{l}\text { Total } \\
\text { Given } \\
\text { (g.) }\end{array}$} & \multirow[b]{2}{*}{$\begin{array}{l}\text { Survival } \\
\text { Time }\end{array}$} & \multirow[b]{2}{*}{ Complications } & \multirow[b]{2}{*}{$\begin{array}{l}\text { Concomitant } \\
\text { Surgery }\end{array}$} \\
\hline & & & & & $\begin{array}{l}\text { Length } \\
\text { of } \\
\text { History }\end{array}$ & $\begin{array}{l}\text { Treatment } \\
\text { Begun }\end{array}$ & $\begin{array}{l}\text { No. of } \\
\text { Doses }\end{array}$ & & & & \\
\hline 1 & W.F. & $\mathbf{F}$ & 55 & $\begin{array}{l}\text { Astrocytoma } \\
\text { (grade IV) }\end{array}$ & $4 \mathrm{mth}$. & 6.1 .60 & 5 & $1 \cdot 1$ & 5 days & - & \\
\hline 2 & C.F. & $\mathbf{M}$ & 62 & $\begin{array}{l}\text { Astrocytoma } \\
\text { (grade III) }\end{array}$ & 4 wk. & 25.1 .60 & 95 & $15 \cdot 7$ & $4 \mathrm{mth}$. & - & \\
\hline 3 & M.W. & $\mathbf{F}$ & 29 & $\begin{array}{l}\text { Metastases } \\
\text { (Ca. colon } 2 \text { yr.) }\end{array}$ & $2 \mathrm{mth}$. & 14.2 .60 & 162 & 18.9 & $6 \mathrm{mth}$. & Alopecia & \\
\hline 4 & V.P. & $\mathbf{F}$ & 59 & $\begin{array}{l}\text { Astrocytoma } \\
\text { (grade III) }\end{array}$ & $3 \mathrm{mth}$. & 18.2.60 & 15 & $2 \cdot 0$ & 17 days & - & \\
\hline 5 & W.H. & $\mathbf{F}$ & 57 & $\begin{array}{l}\text { Astrocytoma } \\
\text { (grade III) }\end{array}$ & 2 wk. & 2.3 .60 & 70 & 8.4 & $3 \mathrm{mth}$. & $\begin{array}{l}\text { Alopecia, } \\
\text { pigmentation }\end{array}$ & \\
\hline 6 & D.R. & $\mathbf{F}$ & 68 & $\begin{array}{l}\text { Astrocytoma } \\
\text { (grade III) }\end{array}$ & 3 wk. & 16.3 .60 & 40 & $5 \cdot 2$ & $4 \mathrm{mth}$. & $\begin{array}{l}\text { Intramuscular } \\
\text { abscess }\end{array}$ & Frontal lobectomy \\
\hline 7 & W.D. & $\mathbf{M}$ & 57 & $\begin{array}{l}\text { Astrocytoma } \\
\text { (grade III) }\end{array}$ & 8 wk. & 26.3 .60 & 16 & $5 \cdot 4$ & $6 \mathrm{mth}$. & $\begin{array}{l}\text { Obstructive } \\
\text { jaundice }\end{array}$ & \\
\hline 8 & A.R. & $\mathbf{F}$ & 40 & $\begin{array}{l}\text { Astrocytoma } \\
\text { (grade III) }\end{array}$ & 5 yr. & 26.3 .60 & 500 & $54 \cdot 0$ & $2 \frac{1}{2}$ yr. & & $\begin{array}{l}\text { Temporal } \\
\text { lobectomy }\end{array}$ \\
\hline 9 & J.P. & $\mathbf{M}$ & 57 & $\begin{array}{l}\text { Astrocytoma } \\
\text { (grade II) }\end{array}$ & $4 \mathrm{mth}$ & 12.4 .60 & 120 & $18 \cdot 2$ & $4 \mathrm{mth}$. & Anaemia & \\
\hline 10 & M.S. & $\mathbf{F}$ & 56 & $\begin{array}{l}\text { Astrocytoma } \\
\text { (grade III) }\end{array}$ & 3 wk. & 20.4 .60 & 242 & $32 \cdot 0$ & $12 \mathrm{mth}$. & Alopecia & Partial excision \\
\hline 11 & V.D. & $\mathbf{F}$ & 43 & $\begin{array}{l}\text { Astrocytoma } \\
\text { (grade III) }\end{array}$ & 3 wk. & 5.5 .60 & 140 & $16 \cdot 2$ & 5 mth. & & $\begin{array}{l}\text { Removal of } \\
\text { tumour }\end{array}$ \\
\hline 12 & L.G. & $\mathbf{F}$ & 60 & $\begin{array}{l}\text { Astrocytoma } \\
\text { (grade IV) }\end{array}$ & 5 wk. & 9.5 .60 & 20 & $4 \cdot 1$ & $1 \mathrm{mth}$. & Anaemia & $\begin{array}{l}\text { Temporal } \\
\text { lobectomy }\end{array}$ \\
\hline 13 & E.S. & $\mathbf{F}$ & 64 & $\begin{array}{l}\text { Astrocytoma } \\
\text { (grade III) }\end{array}$ & $4 \mathrm{mth}$. & 17.6 .60 & 100 & $10 \cdot 0$ & $4 \mathrm{mth}$. & Anaemia & Frontal lobectomy \\
\hline 14 & W.G. & $\mathbf{F}$ & 62 & $\begin{array}{l}\text { Metastases } \\
\text { (ca. breast } 10 \text { yr.) }\end{array}$ & 8 wk. & 15.7 .61 & 39 & $7 \cdot 6$ & $4 \mathrm{mth}$ & Alopecia & \\
\hline
\end{tabular}

tually showed signs of increased intracranial pressure and died five months later of continued growth of tumour.

In the remaining five cases, a good surgical internal decompression was obtained, the patients having had either frontal or temporal lobectomy or removal of a large amount of tumour tissue before the drug was given. In case 6 , owing to marked obesity, prolonged intravenous administration of Endoxana became impossible and it was decided to supplement oral therapy with intramuscular injections of Endoxana. The patient developed a large gluteal abscess with marked pyrexia following the intramuscular injection and Endoxana was discontinued after having been given for three weeks; death occurred three months later from a clinical recurrence of the tumour.

Cases $8,10,12$, and 13 , after showing the initial improvement expected after a surgical decompression, steadily deteriorated and died in one to six months due to continued growth of tumour.

One patient (case 8) remained quite well for eight months and survived for two and a half years from the time therapy was begun.

Thus, although Endoxana had to be discontinued for various reasons in three of the 14 cases, the growth of the tumour was not controlled in any patient in the series and all died within two and a half years.

\section{COMPLICATIONS}

Nausea and vomiting were observed in about a third of the cases for the first two or three days, but could be controlled with Dramamine or Largactil. Excessive leucopenia (below 1,600 per c.mm.) occurred in five cases, but was corrected without difficulty by the temporary witholding of the drug; when properly stabilized, these patients continued to have Endoxana without any excessive leucopenic effect. Three cases showed evidence of iron-deficiency anaemia, which responded to iron therapy. The platelet count was not affected. One patient developed obstructive jaundice which cleared up completely in two weeks after stopping the Endoxana.

The commonest complication was alopecia; nearly all the patients had their heads shaved for surgical procedures and subsequent growth of hair was extremely slow so that it was only after four to five months that hair started growing. Neither case 8 nor case 10 had regained their normal growth of hair after as long a period as 12 months. In two cases in which only a short course of Endoxana was given, the hair soon began to grow again.

\section{DISCUSSION}

Because of the hazards of fractionated intra-arterial injection (Klopp, Alford, Bateman, Berry, and 
Winship, 1950) and cerebral perfusion (Woodhall et al, 1959), it was not felt to be justified to give Endoxana by either of these two techniques unless it was found effective when given systemically. We, therefore, tried its systemic use in 14 cases of cerebral tumour. An earlier report (Simon, 1959) on the use of Endoxana in cerebral neoplasms stated that the drug 'was invariably well tolerated' and that if it was given 'following surgical excision, the prognosis for survival is better'. Our results do not substantiate either of these statements. The only patient surviving longer than eight months without any signs of increased intracranial pressure had had a decompressive lobectomy for an astrocytoma (grade II malignancy), and the result is comparable to the usual progress of a glioma of this grade of malignancy surgically treated. Thenecropsied specimens of the tumour tissue have not shown any significant change which could be attributed to the Endoxana therapy. The drug is, however, safer than other alkylating agents in that the tendency to leucopenia is more easily reversible.

\section{SUMMARY}

Endoxana, a nitrogen mustard derivative, was given systemically in 14 cases of intracerebral tumour; 12 of these tumours were gliomas and two cerebral metastases.

All the patients have died from the continued growth of the tumour. Only one patient survived? longer than 12 months, and in this case the tumour was histologically of low malignancy.

Side-effects included nausea, vomiting, markef alopecia, iron-deficiency anaemia, and severe leuco penia; the last disappeared when the drug was dis continued. In one case, transient obstructive jaundice: occurred.

In this series the systemic administration of Endoxana had no therapeutic effect.

We are grateful to Ward Blenkinsop Ltd. for supplying Endoxana.

\section{REFERENCES}

Klopp, C. T., Alford, C., Bateman, J., Berry, G. N., and Winship, Tळ (1950). Fractionated intra-arterial cancer; chemotherapy with: methyl-bis amine hydrochloride. Ann. Surg., 132, 811-832.

Simon, G. (1959). Chemotherapeutische Versuche beim Glioblastom? Acta neurochir. (Wien), suppl. 6, pp. 187-191.

Woodhall, B., Hall, K., Mahaley, S., and Jackson, J. (1959). Chemo-V therapy of brain cancer: Experimental and clinical studies $i$ i $r$ localized hypothermic cerebral perfusion. Ann. Surg., t50f 640-652.

\section{The August 1964 Issue}

\section{THE AUGUST 1964 ISSUE CONTAINS THE FOLLOWING PAPERS}

Epidemiology and mental disorder: A review MICHAEL SHEPHERD and BRIAN COOPER

Cognitive deficit related to seizure pattern in centrencephalic epilepsy DOREEN KIMURA

Observations on colour agnosia M. KINSBOURNE and ELIZABETH K. WARRINGTON

The effect of hypnotic anaesthesia on cortical responses A. M. HALlidAY and A. A. MASON

Spinal cord compression by extramedullary haematopoiesis in myelosclerosis A. APPLEBY, G. A. BATSON, L. P. LASSMAN, and CHARLES A. SIMPSON

Central pontine myelinolysis J. L. CHASON, J. W. LANDERS, and J. E. GONZALEZ
Angiography study of the middle cerebral artery chronic infantile hemiplegia MARK DYKEN

Superficial haemosiderosis of the central nervous system B. E. TOMLINSON and JOHN N. WALTON

Electroencephalographic changes associated with cere bellar hemisphere tumours PAUL DYKEN, HARRY I MANNING, and PHILIP WHITE

Myasthenia gravis with hypergammaglobulinaemia an antibodies H. J. G. H. OOSTERHUIS, H. VAN DER GELD' T. E. W. FELTKAMP, and F. PEETOOM

Clinical and electrophysiological study of the pattern of conduction times in the distribution of the sciatic nerve M. M. GASSEL and W. TROJABORG

Book reviews

Copies are still available and may be obtained from the PUBLISHING MANAGER, BRITISH MEDICAL ASSOCIATION, TAVISTOCK SQUARE, W.C.I., price 18s. 6D. 